\title{
УДК 341.1
}

Талия ХАБРИЕВА

Залина ХАМЧИЕВА

\section{ВЕНЕЦИАНСКАЯ КОМИССИЯ: ИТОГИ ТРИДЦАТИЛЕТИЯ}

\author{
Статья поступила в редакцию 26.03.2021
}

\begin{abstract}
Аннотация. Статья посвящена итогам тридцатилетней деятельности Европейской комиссии за демократию через право (Венецианской комиссии Совета Европы) - признанного экспертного центра в области конституционного права. Россия участвует в ее работе с 2002 г. Цель статьи - показать эволюцию проблематики заключений Венецианской комиссии: от общих проблем конституционных реформ к конкретизации отдельных институтов, оценке избирательных систем, эффективности правосудия, гарантий гражданских и политических прав граждан. Такой сравнительный анализ способствует формированию наиболее полного представления о значении Комиссии в настоящее время. Рассмотрены основные этапы становления Комиссии, показывающие расширение географической сферы ее влияния и усиление роли в политико-правовой и научной-правовой областях. Проведенное исследование позволяет восполнить очевидный пробел в отечественной науке сравнительного и конституционного права, поскольку специальных работ, посвященных Венецианской комиссии, мало. В статье поставлены задачи, которые могут способствовать формированию новых направлений развития юридической науки с учетом опыта Комиссии и ее вклада в совершенствование институтов демократии. Работа предназначена для ученых, специализирующихся в области сравнительного и конституционного права, преподавателей и студентов, изучающих право Совета Европы. Факультативный семинар по правовым позициям Вене-
\end{abstract}

(C) Хабриева Талия Ярулловна (автор введения и раздела «Функции и перспективы работы Комиссии») - директор Института законодательства и сравнительного правоведения при Правительстве Российской Федерации, заместитель президента Российской академии наук, член Европейской комиссии за демократию через право (Венецианской комиссии Совета Европы), академик Российской академии наук, действительный член Международной академии сравнительного права, доктор юридических наук, профессор, заслуженный деятель науки Российской Федерации, заслуженный юрист Российской Федерации, заслуженный юрист Республики Татарстан. Адрес: 107078, Москва, Б. Харитоньевский пер., д. 22-24, стр. 1А, 1БВ. E-mail: office@izak.ru

(C) Хамчиева Залина Белановна (автор раздела «Формирование и компетенция Комиссии») - аспирантка Института законодательства и сравнительного правоведения при Правительстве Российской Федерации. Адрес: 107078, Москва, Б. Харитоньевский пер., д. 22-24, стр. 1А, 1БВ. E-mail: office@izak.ru

DOI: http://dx.doi.org/10.15211/soveurope320210516 
цианской комиссии организован в магистратуре Института законодательства и сравнительного правоведения при Правительстве Российской Федерации.

Ключевые слова: Венецианская комиссия, демократия, правовое государство, конституция, конституционные реформы, избирательное право, правосудие, права человека, сравнительное право.

\section{Введение}

Среди множества различных экспертных и научных организаций современного мира Европейская комиссия за демократию через право, более известная как Венецианская комиссия, занимает особое место. Она была создана в 1990 г. на конференции 18 государств - членов Совета Европы (CE) на основании Частичного соглашения для содействия демократическим преобразованиям в странах Центральной и Восточной Европы ${ }^{1}$. Комиссия должна была стать временным (на два года) консультативным органом Совета Европы. Однако она продолжила свою деятельность и в настоящее время представляет собой ведущий международный исследовательский и экспертный центр, в работе которого принимают участие представители не только 47 государств - членов Совета Европы, но и государств Азии, Африки, Америки. Иными словами, деятельность Комиссии, несмотря на ее европейскую принадлежность, распространяется на несколько континентов. В зарубежной литературе это нередко обозначается как «транснациональность», отражающая европейские ценности, функции, статус и интернациональный членский состав Комиссии [Craig, 2016: 69].

Другая ее характерная черта состоит в том, что она имеет статус независимого консультативного органа Совета Европы, сохраняя свою автономию по отношению к его органам. Эта специфика закреплена и в отношении ее персонального состава: в Комиссию входят независимые эксперты, получившие международную известность благодаря опыту работы в демократических институтах или вкладу в укрепление права и развитие теоретических наук. Члены Комиссии участвуют в ее деятельности в индивидуальном порядке и не подчиняются никаким инструкциям (статья 2 часть 1 Устава Комиссии).

По мере усиления значимости заключений Венецианской комиссии появились публикации, в которых все чаще изучаются формы и методы ее работы, научные основы и практические результаты ее деятельности [Buquicchio, Granata-Menghini, 2013: 241-253; Buquicchio, Granata-Menghini, 2014: 1-14; Bartole, 2014; Craig, 2016; Pinelli, 2015; Tuori, 2016: 225-246; Hoffmann-Riem, 2014: 579-597]. Ряд научных исследований и комментариев по этой теме подготовлены Институтом законодательства и сравнительного правоведения при Правительстве РФ (далее - Институт законодательства) [Венецианская комиссия: сто шагов..., 2014; Венецианская комиссия: о конституциях..., 2016; Хабриева, 2018; Венецианская комиссия: о проблемах правосудия..., 2018; Венецианская комиссия: о выборах..., 2020; Чиркин, 2019; Ковлер, Фокин, 2020; Каширкина, Морозов, 2020]. Неофициальные переводы заключений Венецианской комиссии, выполняемые Институтом законодательства, размещаются на сайте Комиссии, являются важным источником изучения и попу-

${ }^{1}$ Résolution (90) relative à un accord partiel portant création de la Commission pour la démocratie par le droit - CM/Res (90)6, 10 mai 1990.

Современная Европа, 2021, № 3 
ляризации ее работы в России и других государствах.

Проект под оригинальным названием «Комиссия за демократию через право» был впервые предложен Антонио Ла Перголой - председателем Конституционного суда Италии, ставшим впоследствии министром Итальянской Республики по европейским делам (1987-1989 гг.). Он был убежден, что «устойчивая демократия может быть построена только на надежных конституционных принципах, основанных на верховенстве права» [Dürr, 2010: 356].

\section{Формирование и компетенция Комиссии}

Важной функцией Комиссии, ее своеобразным raison d'être, должно было стать обсуждение и принятие рекомендаций относительно дальнейшего конституционного развития государств, которые на тот момент не являлись членами СЕ, особенно стран Центральной и Восточной Европы. Можно согласиться с тем, что события, происходившие в это время в европейском регионе, и процесс реформирования политических систем в Советском Союзе и странах «социалистического лагеря», оказали значительное влияние на облик Комиссии, ускорили ее формирование и расширили цели [Salinas Alcega, 1999: 5]. По мнению некоторых исследователей, в качестве модели для деятельности Комиссии были взяты высшие консультативные органы на национальном уровне - Государственные советы Франции и Нидерландов, которые дают заключения на законы или их проекты [Van Dijk, 2007: 183].

На момент создания Венецианской комиссии в ее состав входило 18 из 23 государств - членов СЕ. Точные сведения о позиции каждой страны по вопросу вступления в Венецианскую комиссию отсутствуют. Так, бывший член Комиссии Дж. Джоуэлл, который представлял Великобританию с 2000 по 2011 г., указал, что «по неясным причинам Соединенное Королевство не присоединилось к Комиссии в первые десять лет ее существования и направило своего члена только в 2000 г.» [Jowell, 2001: 675].

Ежегодно состав Комиссии пополнялся. В январе 2002 г. после вступления России составы Венецианской комиссии и Совета Европы полностью совпали.

В связи с изменениями в географическом представительстве Венецианская комиссия в 2002 г. была преобразована в формат «расширенного соглашения», которое легализовало возможность участия в ее работе государств, не входящих в Совет Европы, включая страны из других регионов мира. После 2002 г. деятельность Венецианской комиссии приобрела почти мировой масштаб. Как отметил К. Туори, «с точки зрения состава членов Комиссия превратилась из европейского клуба в глобальный, транснациональный конституционный форум» [Tuori, 2016: 2]. Напомним, что Европейская комиссия за демократию через право насчитывает 62 полноправных члена, из которых 47 - члены Совета Европы, а остальные 15 находятся в других регионах мира.

Цели, определенные при создании Комиссии, широкая компетенция и географическое расширение состава предопределили своеобразие форм и методов ее практической деятельности. Следует отметить, что интерпретация Венецианской комиссией национального права в процессе формирования ее «мнения» (opinion) довольно новый феномен и для международного, и для национальных правопорядков. Акты Венецианской комиссии как результат толкования национального права имеют рекомендательно-разъяснительный характер, нередко именуются в науке 
актами «мягкого права» и отличаются рядом нестандартных характеристик и свойств [Хабриева, 2018: 55-67]. Исследователи показывают, что механизм существенного влияния Комиссии на конституционные процессы при одновременном уважении национального суверенитета стал инновационным решением в Европе, в отличие от того, каким образом происходило распространение сферы влияния Европейского Союза в данном направлении [Hardman, Dickson, 2019: 30-49].

К компетенции Комиссии относятся прежде всего проблемы демократии и конституционализма, включая избирательное право, права человека, законодательство о судебной системе, институт омбудсмена и др. В связи с этим ряд исследователей полагают, что компетенция Комиссии не имеет определенных правовых границ и «в ее распоряжении имеется целый экспертный арсенал в сферах конституционного, административного и уголовного права, публичного международного права, права прав человека и гуманитарного права» [Van Dijk, 2007: 185-186].

Принятие новых конституций в Центральной и Восточной Европе при содействии Венецианской комиссии в 1990-х гг. позволило говорить об «интернационализации конституционного права», появлении «международного конституционализма», «конвергенции конституций», общем «европейском конституционном наследии» [Bartole, 2014; Чиркин, 2013: 82-86]. Впоследствии большинство запросов в Комиссию стало затрагивать более детальные и частные вопросы - «баланс властей», соотношение полномочий главы государства, исполнительной и законодательной власти, место и роль органов правосудия.

Результатом обобщения позиций Венецианской комиссии по вопросам конституционных реформ стал аналитический Доклад о конституционных поправках [Beнецианская комиссия: о конституциях..., 2016: 24-94] и модельный регламент о проведении конституционных референдумов на национальном уровне [Венецианская комиссия: о конституциях..., 2016: 105-115]. Следует особо отметить, что по этому вопросу Венецианская комиссия занимает весьма взвешенную позицию: «Вопрос о конституционных поправках лежит в основе конституционной теории и практики. Конституционализм означает, что основные правила эффективного осуществления государственной власти и защиты индивидуальных прав человека должны быть стабильными и предсказуемыми и не должны быть легко изменяемыми. Это очень важно для легитимности конституционного строя. В то же время фундаментальное изменение конституции иногда необходимо для того, чтобы улучшить демократическое управление или приспособиться к политическим, экономическим и социальным преобразованиям» [Венецианская комиссия: о конституциях..., 2016: 25].

Важно и другое заключение о процедурах изменения конституции: «Это общие фундаментальные элементы механизмов конституционных изменений, но они формулируются и сочетаются в столь же большом количестве вариантов, сколько существует конституций. В Европе они варьируются в диапазоне от государств, в которых конституционные изменения осуществляются довольно легко, до государств, где на практике это почти невозможно. Не существует единой европейской «лучшей модели» принятия поправок к конституции и тем более общих обязательных правовых требований. До сих пор не было даже попыток сформулировать какие-либо общие европейские стандарты» [Венецианская комиссия: о конституциях..., 2016: 25]. 
Конституционные реформы часто сопровождаются изменениями в избирательных системах. Одним из первых документов компаративистского характера, содержащих рекомендуемые стандарты в области избирательного права, стал разработанный Венецианской комиссией и ее Советом по демократическим выборам Кодекс надлежащей практики проведения выборов (2002), следующим - Кодекс надлежащей практики проведения референдумов (2007), которому предшествовало исследование Комиссии «Референдумы в Европе: анализ правовых норм в европейских государствах» (2005). Несколько докладов и исследований касались участия в выборах национальных меньшинств и женщин. В последнее десятилетие вышли в свет такие актуальные документы, как доклады «О голосовании за рубежом» (2011) и «О злоупотреблении административным ресурсом в ходе избирательных процессов» (2013). Комиссия занимается обновлением этих рекомендаций [Венецианская комиссия: о выборах..., 2020]. Так, в 2019 г. опубликован доклад «Об использовании цифровых технологий в избирательных кампаниях» [Венецианская комиссия: о выборах..., 2020: 141-205].

Необходимо рассмотреть еще одно направление деятельности Комиссии. С конца 1990-х гг. при ее участии укрепляется сотрудничество конституционных и иных высших судов европейских стран, появляются структурированные, институционализированные модели такого взаимодействия. Наиболее крупным проектом Комиссии в данной области стало создание международного форума конституционных судей - Всемирной конференции конституционного правосудия (World Conference on Constitutional Justice, WCCJ). Она объединяет 112 конституционных судов и советов, а также верховных судов из Европы, Африки, Америки, Азии, Австралии/Океании. Под эгидой Комиссии действуют Совместный совет по конституционному правосудию и Венецианский форум конституционных судов.

Конституционному правосудию посвящена значительная часть исследований Венецианской комиссии. Среди них доклад «О формировании конституционных судов» $(1996)^{1}$, Решения конституционных судов и эквивалентных им органов и их исполнение $(2001)^{2}$, Справочник по конституционному правосудию $(2004)^{3}$, Исследование на тему индивидуального доступа к конституционному правосудию $(2010)^{4}$, Правовые позиции, доклады и исследования Венецианской комиссии по конституционному правосудию (2015) [Венецианская комиссия: о конституциях..., 2016: 116-195].

В целях взаимного обмена информацией между высшими судебными инстанциями Венецианская комиссия с 1992 г. сформировала Центр документации. С 1993 г. она выпускает Бюллетень практики конституционных судов (The Bulletin on Constitutional Case-Law), в котором отражены резолюции наиболее значимых решений более 60 конституционных и иных высших судов, конституционных палат. Комиссия также ведет интернет-базу CODICES $^{5}$, где публикуются решения консти-

${ }^{1}$ CDL-JU(96)8.

${ }^{2}$ CDL-INF(2001)009-e.

${ }^{3}$ CDL-JU(2006)029.

${ }^{4}$ Доклад, принятый на 85-й пленарной сессии (Венеция, 17-18 декабря 2010 г.). Обновлен в 2020 г.

${ }^{5}$ URL: www.CODICES.coe.int (дата обращения: 09.03.2021)

Современная Европа, 2021, № 3 
туционных судов в полном объеме, а также законодательные положения, регулирующие их статус, регламенты, структуру, другая значимая правовая информация (более чем на 40 языках).

Суммируя важнейшие направления работы Венецианской комиссии, можно отметить, что она не только является единственным органом Совета Европы, разрабатывающим заключения научно-практического характера по вопросам конституционного права. Ее рекомендательные акты и правовые позиции оказывают влияние на развитие других отраслей национального права государств. Стали распространенными экспертные оценки проектов гражданского или уголовного кодекса в части, касающейся, например, статуса СМИ или антикоррупционных санкций в отношении депутатского, судейского корпуса, деятельности общественных организаций. Не оставлены без внимания и проблемы национальных меньшинств в ряде законов об образовании. Тем самым тематика заключений и докладов Комиссии за последнее десятилетие радикально обновилась.

Кроме того, Комиссия неоднократно играла роль посредника в предотвращении и разрешении конституционных кризисов в государствах-участниках, в том числе благодаря сотрудничеству с конституционными судами, судами общей юрисдикции и омбудсменами. Однако в настоящее время активизировались попытки оппозиционных деятелей в ряде стран вовлечь Венецианскую комиссию в политическое противостояние, инициируя через «сочувствующих» депутатов ПАСЕ запросы, на которые она, согласно Уставу, должна реагировать.

В 1980-х гг., как отмечает председатель Комиссии Джанни Букиккио, идея Beнецианской комиссии была встречена «с подозрением», поскольку конституционное право всегда считалось «собственной вотчиной» каждого государства [Buquicchio, Granata-Menghini, 2013: 241]. Теперь же созданная в 1990 г. и востребованная в XXI в. Комиссия считается одним из ведущих международных интерпретаторов права. При этом толкование права Комиссией чаще всего принимает форму поиска соотношения так называемого транснационального правопорядка и национального права [Хабриева, 2018].

\section{Функции и перспективы работы Комиссии}

В процессе интерпретационной деятельности Комиссия выполняет несколько юридически значимых функций. Одной из них является участие в модернизации национального права, о котором говорилось выше. Другая функция выражается в гармонизации (унификации) права за счет объединения правовых позиций самой Венецианской комиссии, ЕСПЧ, других органов Совета Европы, способов и методов толкования, исторически сложившихся правовых стандартов в сочетании с практикой, привнесенной «новыми демократиями», и с привлечением конституционных идей и доктрин.

Всеобщее признание получил доклад Венецианской комиссии «О верховенстве права» [Венецианская комиссия: о проблемах правосудия..., 2018: 34-53] - результат многолетнего исследования членов Венецианской комиссии и привлеченных экспертов. Несмотря на наличие нюансов в понятиях «верховенство закона» (Rule of Law) и «правовое государство» (Rechtsstaat, Etat de droit) в различных правовых системах, Комиссия подчеркивает: «Верховенство права само по себе является не- 
отьемлемой частью любого демократического общества, и понятие «верховенство права» требует, чтобы все официальные лица относились к любому человеку с уважением, соблюдая принцип равенства, рационально и на основе права, а также чтобы у каждого была возможность обжаловать любые решения в независимых и беспристрастных судах, если эти решения являются незаконными» (пункт 16).

Говоря о достижениях Комиссии, не следует забывать о сложностях и особых условиях ее деятельности.

Объекты толкования в области права многозначны, далеко не всегда достаточно четко сформулированы и имеют определенную политическую цель, поскольку право, особенно конституционное, - политическое явление. Кроме того, они становятся отражением разных правовых культур, содержат особенности, определяемые спецификой той или иной правовой системы. География работы Комиссии продолжает расширяться; и сами эксперты - толкователи, и адресаты ее рекомендаций представляют различные культурные и ценностные системы, правовые практики. При столкновении неодинаковых (или неодинаково понимаемых и даже противоречивых) ценностей и интересов очень важны поиск оптимального баланса общего и особенного, осторожное разрешение коллизий и опасений, восприятие возможных исключений при убежденности экспертов в истинности собственной правовой «картины мира». Хотя эксперты Комиссии считаются формально независимыми, по мере обострения международной обстановки все чаще звучат упреки в их излишней политизированности, а также в недостаточном учете национального своеобразия различных стран.

В соответствии с Уставом Комиссия призвана «продвигать основные ценности правового государства, прав человека и демократии». Данная задача предполагает некую оценку соответствия национального права этим ценностям. Между тем каждая из таких ценностей имеет множество смыслов. Так, в литературе отмечаются «пестрота терминологии и крайняя политизированность» в понятии и признаках демократии [Ковлер, 1990: 55-107; Матье, 2021], сложность формулирования стандартов в рамках «демократии», поскольку они представляют собой довольно серьезное вмешательство в национальный суверенитет [Pinelli, 2015]. Весьма непростой задачей представляется научная интерпретация концепции «верховенства права» (и «правового государства»), которой посвящены упомянутые специальные исследования Комиссии - доклад «О верховенстве права» (2011) и Контрольный список вопросов по соблюдению верховенства права (2016). Многие страны ссылаются в своих конституциях на принцип «правового государства», однако он не имеет универсальной содержательной трактовки. Скорее, существуют его «национальные разновидности» и толкования в соответствии с правовой и политической культурой того или иного государства. Венецианская комиссия стремится учитывать эти особенности, но нередко в ее заключениях по отдельным странам просматривается тенденция к унификации модели правового государства.

Можно предположить, что уже в ближайшей перспективе Комиссия будет сталкиваться со сложными и неоднозначными процессами, происходящими в современном праве. Так, многими авторами констатируется резкое расширение сфер конституционного регулирования на данном этапе развития мирового конституционализма, появление новых конституционно-правовых институтов. В связи с этим правомерна постановка вопроса о возникновении особой модели инструмен-

Современная Европа, 2021, № 3 
тально-социальной конституции [Хабриева, 2013: 39]. В таких конституциях шире и многообразнее, чем ранее, закрепляются основы экономической и социальной жизни общества, социальные функции собственности и предпринимательства, взаимная социальная ответственность, инструменты социального партнерства, принципы взаимодействия политических партий с органами власти, вопросы деятельности оппозиции, новые индивидуальные и коллективные права.

Очередные волны конституционных и законодательных реформ в отдельных районах мира свидетельствуют в пользу того, что мировая эволюция права нуждается в модернизации самой концепции конституционализма. В связи с этим нельзя исключать усиления роли Венецианской комиссии как центра инициации научных и экспертных дискуссий, способствующих формированию планетарного конституционного правопонимания. Право постмодерна и нового информационного общества имеет тенденцию к активной трансформации в части своих фундаментальных постулатов, которые неизбежно будут восприниматься как глобальноуниверсальные.

Вместе с тем в современных правопорядках наметились и иные, противоположные тренды. Общемировые кризисные явления и тенденции к дезинтеграции, характерные для второго десятилетия XXI в., вызвали стремление к переоценке многими цивилизациями так называемых универсальных ценностей. В конституциях различных государств все чаще закрепляются особые, поддерживаемые обществом и активно защищаемые государством традиционные ценности, институты собственной культуры и права, трактуемые в контексте национальной идентичности. Полагаем, надо признать правоту тех исследователей, которые считают, что с расширением географии заключений Комиссии и спектра анализируемых ею политических и правовых систем возникает необходимость более осторожного и взвешенного подхода в продвижении принципов, которые до недавнего времени казались бесспорно универсальными [Хабриева, 2021: 6-12].

Можно предположить, что работа Венецианской комиссии при всей противоречивости нынешних социально-политических процессов требует углубленной специализации в ряде вопросов, относящихся к новой правовой проблематике, связанной с научно-технической революцией. Это очень большое поле деятельности, в том числе в области прав человека - от киберпреступности до правового регулирования применения искусственного интеллекта, от «дистанционной формы существования〉 социума (особенно в условиях эпидемий) до биоэтики. Комиссия начала осваивать сравнительно новую сферу, например, рассматривала проекты законов Молдовы и Албании об аудиовизуальных медиауслугах (медиаслужбе), а в 2019 г. выступила с докладом «Об использовании цифровых технологий в избирательном праве» [Венецианская комиссия: о выборах..., 2020: 141-205] ${ }^{1}$.

Обмен идеями и информацией между Институтом законодательства и Венецианской комиссией позволяет инициировать разработку новых концепций в конституционализме и юридической науке в целом, применять их при изменении российского законодательства, особенно в свете поправок к Конституции России 2020 г. Большой вклад в эту работу вносят ежегодные конгрессы сравнительного правоведения, проводимые совместно Институтом и Комиссией. Работа таких конгрессов

${ }^{1} \mathrm{CDL}-\mathrm{AD}(2019) 016$.

Современная Европа, 2021, № 3 
позволяет исследовать зарубежный конституционный опыт, включая «европейские стандарты», осмыслить внутреннюю взаимосвязь общих и сугубо внутригосударственных принципов права, универсальных и национальных ценностей. Особое значение при этом приобретают вопросы охраны государственного суверенитета, актуальность которых обострилась практически во всем мире и получила отражение в обновленной российской Конституции.

Работа делегации Российской Федерации в Венецианской комиссии, а также заключения Комиссии по российскому законодательству - большая, многоплановая и отдельная тема. За годы сотрудничества с Россией Венецианской комиссией было вынесено более 20 заключений по проектам Конституции 1993 г. и федеральным законам. В условиях международных трендов участие представителей России в работе Комиссии является важным каналом выстраивания конструктивного диалога и обмена мнениями с учеными, практикующими юристами, общественными деятелями из всех регионов мира. Институт законодательства постоянно информирует общественность об этом направлении его деятельности [Khabrieva, 2020: 393-399; Кошелева, Лебедева, 2017; Лебедева, 2017; Чиркин, Лебедева, Кузнецова, 2018; Чиркин, Лебедева, 2020; Каширкина, 2021].

В связи с юбилеем Венецианской комиссии уместно напомнить об идее «общеевропейского дома» и о советско-французской инициативе создания европейского правового пространства [Горбачев, 2010: 149-154; Лесаж, 1989], поскольку именно опыт Комиссии служит ярким примером стремления к реализации этой идеи.

\section{Список литературы}

Венецианская комиссия: о выборах и избирательных технологиях. (2020) Под ред. Т.Я. Хабриевой. Москва, Россия.

Венецианская комиссия: о конституциях, конституционных поправках и конституционном правосудии. (2016) Под ред. Т.Я. Хабриевой. Москва, Россия.

Венецианская комиссия: о проблемах правосудия в современном мире. (2018) Под ред. Т.Я. Хабриевой. Москва, Россия.

Венецианская комиссия: сто шагов к демократии через право. (2014) Москва, Россия.

Горбачев М.С. (2010) Собрание сочинений. Весь мир, Москва, Россия. Т. 15.

Каширкина А.А. (2021) Обзоры пленарных заседаний Венецианской комиссии. Журнал зарубежного законодательства и сравнительного правоведения. № 1. № 2. URL: https://orcid.org/0000-00024269-8262 (дата обращения: 12.03.2021)

Каширкина А.А., Морозов А.Н. (2020) Теоретические подходы Европейской комиссии за демократию через право (Венецианской комиссии) к оценке законодательства о противодействии терроризму: международно-правовой дискурс и проблемы имплементации. Всероссийский криминологический журнал. Т. 14. № 3 .

Ковлер А.И. (1990) Исторические формы демократии: проблемы политико-правовой теории. Москва, Россия.

Ковлер А.И., Фокин Е.А. (2020) «Старые» и «новые» проблемы конституционализма в заключениях и докладах Венецианской комиссии. Сравнительное конституционное обозрение. № 3 .

Кошелева Е.В., Лебедева Я.И. (2017) «Маленькая Венеция» не соответствует стандартам «большой» (анализ предварительного заключения Европейской Комиссии за демократию через право № CDL-PI(2017)004 по законодательству Венесуэлы). Журнал зарубежного законодательства и сравнительного правоведения. № 6. DOI: 10.12737/article_5a1e71d904dd41.95432293

Лебедева Я.И. (2017) Правовой анализ заключения Венецианской комиссии на проект изменений, вносимых в конституцию Турецкой Республики. Журнал зарубежного законодательства и сравнительного правоведения. № 3. DOI: 10.12737/article_593fc343e44b56.34892143 
Лесаж М. (1989) Права человека, правовое государство и европейское правовое пространство. Права человека в истории человечества и в современном мире. Изд-во ИГП АН СССР, Москва, Россия.

Матье Б. (2021) Право против демократии? Пер. с франц. Москва, Россия.

Хабриева Т.Я. (2018) Венецианская комиссия как субъект интерпретации права: монография. Москва, Россия.

Хабриева Т.Я. (2013) Генезис конституции и основные конституционные модели. Конституция Российской Федерации. От образа будущего к реальности. К 20-летию Основного Закона России: монография. Под ред. Т.Я. Хабриевой. Москва, Россия.

Хабриева Т.Я. (2021) Конституционная реформа в России в координатах универсального и национального. Журнал зарубежного законодательства и сравнительного правоведения. Т. 17. № 1. С. 6-12. DOI: $10.12737 /$ jflcl.2021.001

Чиркин С.В., Лебедева Я.И. (2018) Конституция Российской Федерации в оценке Европейской комиссии за демократию через право. Журнал зарубежного законодательства и сравнительного правоведения. № 6.

Чиркин С.В., Лебедева Я.И., Кузнецова М.С. (2020) Обзор деятельности Европейской комиссии за демократию через право (Венецианской комиссии) в 2019 г. Журнал зарубежного законодательства и сравнительного правоведения. № 2 .

Чиркин С.В. (2019) Венецианская комиссия Совета Европы как исследовательский центр проблем интеграции. Исследовательские центры международных организаций и их вклад в развитие правового регулирования региональной интеграции на евразийском пространстве: монография. Под общ. ред. А.И. Ковлера. Москва, Россия.

Чиркин. С.В. (2013) Зарубежный конституционализм: опыт развития. Конституция Российской Федерации. От образа будущего к реальности. К 20-летию Основного Закона России: монография. Под ред. Т.Я. Хабриевой. Москва, Россия.

\section{References}

Bartole S. (2014) International Constitutionalism and Conditionality: the Experience of the Venice Commission. Rivista No 4/2014, Associazione dei Constituzionalisti Italiani.

Buquicchio G., Granata-Menghini S. (2014) Conseil de l'Europe - Commission de Venise, Rép. eur. Dalloz, avril 2014.

Buquicchio G. and Granata-Menghini S. (2013) The Venice Commission Twenty Years on: Challenge Met but New Challenges Ahead. Fundamental Rights and Principles - Liber amicorum Pieter van Dijk, Cambridge, Antwerp, Portland.

Chirkin S.V., Lebedeva Ya.I. (2018) Konstitutsiya Rossijskoj Federatsii v otsenke Venetsianskoj komissii za demokratiyu cherez pravo [The Constitution of the Russian Federation in the assessment of the European Commission for Democracy through Law]. Zhurnal zarubezhnogo zakonodatel'stva i sravnitel'nogo pravovedeniya. No 6. (in Russ.).

Chirkin S.V., Lebedeva Ya.I., Kuznetsova M.S. (2020) Obzor deyatel'nosti Evropejskoj komissii za demokratiyu cherez pravo (Venetsianskoj komissii) v $2019 \mathrm{~g}$. [Review of the activities of the European Commission for Democracy through Law (Venice Commission) in 2019]. Zhurnal zarubezhnogo zakonodatel'stva i sravnitel'nogo pravovedeniya. No 2. (in Russ.).

Chirkin S.V. (2019) Venetsianskaya komissiya Soveta Evropy kak issledovatel'skij tsentr problem integratsii. Issledovatel'skie tsentry mezhdunarodnykh organizatsij i ikh vklad v razvitie pravovogo regulirovaniya regional'noj integratsii na evrazijskom prostranstve: monografiya. [The Venice Commission of the Council of Europe as a research center for integration problems. Research Centers of International Organizations and Their Contribution to the Development of Legal Regulation of Regional Integration in the Eurasian Space: monograph]. Pod obshh. red. A.I. Kovlera. Moscow, Russia. (in Russ.).

Chirkin. S.V. (2013) Zarubezhnyj konstitutsionalizm: opyt razvitiya. Konstitutsiya Rossijskoj Federatsii. Ot obraza budushhego k real'nosti. K 20-letiyu Osnovnogo Zakona Rossii: monografiya. [Foreign constitutionalism: experience of development. The Constitution of the Russian Federation. From the Image of the Future to Reality. To the 20th Anniversary of the Basic Law of Russia: monograph]. Pod red. T.Y. Khabrievoj. Moscow, Russia. (in Russ.). 
Craig P. (2016) Transnational Constitution-Making: The Contribution of the Venice Commission. UCI Journal of International, Transitional and Comparative Law, October 1, 2016.

Dürr R. (2010) The Venice Commission. Council of Europe (edited by E.J. Kleinsorge). The Netherlands: Wolters Kluwer.

Gorbachev M.S. (2010) Sobranie sochinenij [Collected works]. Ves' mir, Moscow, Russia. Vol. 15. (in Russ.).

Hardman H., Dickson B. (ed.) (2019) Electoral Rights in Europe: Advances and Challenges. Routledge, 2019.

Hoffmann-Riem W. (2014) The Venice Commission of the Council of Europe - Standards and Impact. The European Journal of International Law. Vol. 25. No 2.

Jowell J. (2001) The Venice Commission - Disseminating Democracy through Law, Public Law, No 1.

Kashirkina A.A. (2021) Obzory plenarnykh zasedanij Venetsianskoj komissii. [Reviews of the plenary sessions of the Venice Commission]. Zhurnal zarubezhnogo zakonodatel'stva i sravnitel'nogo pravovedeniya. No 1. No 2. URL: https://orcid.org/0000-0002-4269-8262 (accessed: 12.03.2021) (in Russ.).

Kashirkina A.A., Morozov A.N. (2020) Teoreticheskie podkhody Evropejskoj komissii za demokratiyu cherez pravo (Venetsianskoj komissii) $\mathrm{k}$ otsenke zakonodatel'stva o protivodejstvii terrorizmu: mezhdunarodno-pravovoj diskurs i problemy implementatsii. [Theoretical approaches of the European Commission for Democracy through Law (Venice Commission) to the assessment of legislation on countering terrorism: international legal discourse and problems of implementation]. Vserossijskij kriminologicheskij zhurnal. Vol. 14. No 3. (in Russ.).

Khabrieva T.Y. (2018) Venetsianskaya komissiya kak sub"ekt interpretatsii prava: monografiya. [The Venice Commission as a Person for the Interpretation of Law: monograph]. Moscow, Russia. (in Russ.).

Khabrieva T.Y. (2013) Genezis konstitutsii i osnovnye konstitutsionnye modeli. Konstitutsiya Rossijskoj Federatsii. Ot obraza budushhego k real'nosti. K 20-letiyu Osnovnogo Zakona Rossii: monografiya. [Genesis of the Constitution and basic constitutional models. The Constitution of the Russian Federation. From the Image of the Future to Reality. To the 20th Anniversary of the Basic Law of Russia: monograph]. Pod red. T.Ya. Khabrievoj. Moscow, Russia. (in Russ.).

Khabrieva T.Y. (2021) Konstitutsionnaya reforma v Rossii v koordinatakh universal'nogo i natsional'nogo. [Constitutional Reform in Russia in Universal and National Dimensions]. Zhurnal zarubezhnogo zakonodatel'stva i sravnitel'nogo pravovedeniya. Vol. 17. No 1, pp. 6-12. DOI: 10.12737/jflcl.2021.001 (in Russ.).

Khabrieva T. (2020) Russia and the Venice Commission. Venice Commission. Thirty - year Quest for Democracy through Law. Lund.

Kovler A.I. (1990) Istoricheskie formy demokratii: problemy politiko-pravovoj teorii. [Historical Forms of Democracy: Problems of Political and Legal Theory]. Moscow, Russia. (in Russ.).

Kovler A.I., Fokin E.A. (2020) «Starye» i «novye» problemy konstitutsionalizma v zaklyucheniyakh i dokladakh Venetsianskoj komissii. ["Old" and "new" problems of constitutionalism in the conclusions and reports of the Venice Commission]. Sravnitel'noe konstitutsionnoe obozrenie. No 3. (in Russ.).

Kosheleva E.V., Lebedeva Ya.I. (2017) «Malen'kaya Venetsiya» ne sootvetstvuet standartam «bol'shoj» (analiz predvaritel'nogo zaklyucheniya Evropejskoj Komissii za demokratiyu cherez pravo № CDLPI(2017)004 po zakonodatel'stvu Venesuehly). ["Little Venice" does not meet the standards of a "Big" one (analysis of the Preliminary opinion of the European Commission for Democracy through Law No. CDL-PI (2017)004 on the legislation of Venezuela)]. Zhurnal zarubezhnogo zakonodatel'stva i sravnitel'nogo pravovedeniya. No 6. DOI: 10.12737/article_5a1e71d904dd41.95432293 (in Russ.).

Lebedeva Ya.I. (2017) Pravovoj analiz zaklyucheniya Venetsianskoj komissii na proekt izmenenij, vnosimykh v konstitutsiyu Turetskoj Respubliki. [Legal analysis of the Opinion of the Venice Commission on the draft amendments to the Constitution of the Turkish Republic]. Zhurnal zarubezhnogo zakonodatel'stva $i$ sravnitel'nogo pravovedeniya. No 3. DOI: 10.12737/article_593fc343e44b56.34892143 (in Russ.).

Lesazh M. (1989) Prava cheloveka, pravovoe gosudarstvo i evropejskoe pravovoe prostranstvo. Prava cheloveka $\mathrm{v}$ istorii chelovechestva i v sovremennom mire. [Human rights, the Legal State and the European Legal Space. Human rights in the history of mankind and in the modern world]. Izd-vo IGP AN SSSR. Moscow, Russia. (in Russ.).

Mat'e B. (2021) Pravo protiv demokratii? [Law versus Democracy?] Per. s frants. Moscow, Russia. (in Russ.).

Pinelli C. (2015) Parliaments, Constitutional Transitions and the Venice Commission. Report at the LUISS Summer School on "Parliamentary Democracy in Europe", Rome, 23 July 2015.

Современная Европа, 2021, № 3 
Salinas Alcega S. (1999) La Comisión para la democracia a través del Derecho (Comisión de Venecia). Zaragoza.

Tuori K. (2016) From a European to a universal constitutional heritage? Venice Commission - Opinion CDL-Pl (2016)015// Conference on Global constitutional discourse and transnational constitutional activity, Venice, 2016, 7 December.

Tuori K. (2016) From Copenhagen to Venice. Closa C. and Kochenov D. (eds.). Reinforcing Rule of Law Oversight in the European Union.

Van Dijk P. (2007) The Venice Commission on certain aspects of the European Convention of Human Rights. Breitenmoser (ed.): Human Rights, Democracy and the Rule of Law - Liber amicorum Luzius Wildhaber, Zürich.

Venetsianskaya komissiya: o vyborakh i izbiratel'nykh tekhnologiyakh. [The Venice Commission: on Elections and Electoral Technologies]. (2020) Pod red. T.Y. Khabrievoj. Moscow, Russia. (in Russ.).

Venetsianskaya komissiya: o konstitutsiyakh, konstitutsionnykh popravkakh i konstitutsionnom pravosudii. [Venice Commission: about the Constitutions, Constitutional Amendments and Constitutional Justice]. (2016) Pod red. T.Y. Khabrievoj. Moscow, Russia. (in Russ.).

Venetsianskaya komissiya: o problemakh pravosudiya v sovremennom mire. [The Venice Commission: on the Problems of Justice in the Modern World]. (2018) Pod red. T.Y. Khabrievoj. Moscow, Russia. (in Russ.).

Venetsianskaya komissiya: sto shagov k demokratii cherez pravo. [Venice Commission: One Hundred Steps to Democracy through Law] (2014) Moscow, Russia. (in Russ.).

\section{The Venice Commission: the 30 Years of History}

Received 26.03.2021

Authors: Khabrieva T., Director of the Institute of Legislation and Comparative Law under the Government of the Russian Federation, Deputy President of the Russian Academy of Sciences, Member of the European Commission for Democracy through Law (Venice Commission of the Council of Europe), Member of the Russian Academy of Sciences, Titular Member of the International Academy of Comparative Law Doctor of Law, Professor, Honored Science Worker of the Russian Federation, Honored Lawyer of the Russian Federation, Honored Lawyer of the Republic of Tatarstan. Address: p. 1A, 1BV, B. Kharitonyevsky lane, 22-24, Moscow, Russia, 107078. E-mail: office@izak.ru

Khamchieva Z., Postgraduate Student, Institute of Legislation and Comparative Law under the Government of the Russian Federation. Address: p. 1A, 1BV, B. Kharitonyevsky lane, 22-24, Moscow, Russia, 107078. E-mail: office@izak.ru

Abstract. The article is dedicated to the results of thirty years activity of the European Commission for Democracy through Law (Venice Commission of the Council of Europe), which is a recognized expert center in the field of constitutional law. Russia has been participating in its work since 2002. The purpose of the article is to show the evolution of the VC expert opinions' problematics from the general problems of constitutional reforms to the specification of individual institutions, the assessment of electoral systems, the effectiveness of justice, guarantees of civil and political rights of citizens. This comparative analysis contributes to a better understanding of the Commission's current activities. The main stages of the Commissions' formation are considered. The authors explore the expansion of the geographical sphere of Venice Commission's influence and the strengthening of its role in the political-legal and scientific-legal fields. The conducted research makes it possible to fill an obvious gap in the domestic science of comparative and constitutional law, since there are only a few special works dedicated to the Venice Commission. The article sets out tasks that can contribute to the shaping of new directions for the development of legal science, taking into account the experience of the Commission and its contribution to the improvement of democratic institutions. The work is intended for scientists specializing in comparative and constitutional law, teachers and students studying the law of the Council of Europe. An optional seminar on the legal positions of the Venice Commission was organized at the Master's program of the Institute of Legislation and Comparative Law under the Government of the Russian Federation.

Keywords: Venice Commission, democracy, rule of law, constitution, constitutional reforms, electoral law, justice, human rights, comparative law.

DOI: http://dx.doi.org/10.15211/soveurope320210516

Современная Европа, 2021, № 3 